\title{
Towards democratic foundations: a Habermasian perspective on the politics of education
}

\author{
MIKAEL CARLEHEDEN
}

\begin{abstract}
A central aspect of education has always been the passing on of norms and values. This task is not fulfilled if pupils only learn the meaning of established norms and values. It is also about making pupils believe in them and to act according to them. Thus, teaching is also a kind of political socialization. The values taught change historically and this change is related to the political history of a society. Western societies currently are in the middle of a normative transformation. The question is which normative significance this general social transformation has for contemporary education. The answer is that schools should make a radicalized understanding of democratic citizenship its normative foundation. Jürgen Habermas's theory of democracy is the general point of departure.
\end{abstract}

Keywords: democracy; educational policy; Habermas; normative transformation of society.

Education has never only been about teaching facts about the world. It has also, more or less explicitly, been about the passing on to pupils of those values and norms that a society in general upholds. Education in general has meaning only in a normative context. In this sense, it has always been founded on a normative conception. ${ }^{1}$ From a functionalistic perspective one could say that the school is one of the most important instruments that a modern society has to reproduce itself normatively. However, as society changes the content of political socialization also changes. Thus, if historical changes in the politics of education are to be understood, they have to be related to the normative transformation of a society in general. This paper tries to do just that. However, the purpose is not only to clarify changes in educational policy, but also to show that contemporary education needs a normative foundation of a specific kind. The general claim is that the best theoretical point of departure for working out such a foundation is to be found in the work of the German philosopher, Jürgen Habermas. This can be called a deliberative democratic foundation. ${ }^{2}$

In the first part of the paper I give some general sociological, historical, and philosophical arguments for such a democratic foundation. In the second part, these general arguments are related to the politics of education.

Mikael Carleheden is associate professor of sociology in the Department of Social and Political Sciences, Örebro University, SE-701 82 Örebro, Sweden; e-mail: mikael.carleheden@sam.oru.se. His research interests centre on the social and cultural conditions of democracy, the social and cultural conditions of personal identity, and social transformation in general. His most recent book, co-edited with M. H. Jacobsen, is The Transformation of Modernity: Aspects of the Past, Present, and Future of an Era (Aldershot, UK: Ashgate, 2001). 
This connection will be made with the help of - first and foremost-Tomas Englund's investigations of the different Swedish conceptions of education during the $20^{\text {th }}$ century. Swedish educational policy will be used as a case in order to both examine the general arguments in part one and link them to an educational context.

\section{Normative transformation of modern society and its consequences}

The sociological argument for a democratic foundation can be made briefly. In a modern context law and democracy can simply be said to be the answer to Georg Simmel's fundamental sociological question 'How is society possible?' The political authority of religion is replaced in a modern society by the rule of law and democracy (Habermas 1996: xiii). Social integration in a secularized society presupposes the legitimacy of such institutions. In the modern situation of pluralization and privatization of faith - and of conceptions of the good in general - these institutions are, in the last instance, the cement that holds societies together. Thus, conceptions of private and public autonomy are the fundamental norms of modernity, and it should then also be expected that such norms dominate in modern schools. However, these norms have historically been institutionalized in different ways, and it is partly on the grounds of such historical transformations within modernity that it is possible to write a history of modern society and talk about different epochs of modernity. ${ }^{3}$ In the last chapter of Between Facts and Norms, Habermas uses different 'paradigms of law' as a kind of empirical material in order to write such a history. Thus, I turn now to the historical argument for a democratic foundation. ${ }^{4}$

Habermas distinguishes between a liberal-bourgeois, a social-welfare, and proceduralist paradigm of law. ${ }^{5}$ The second succeeded the first during the first half of the $20^{\text {th }}$ century, and during the last quarter of the $20^{\text {th }}$ century the second paradigm ended up in crisis. Contemporary society may be characterized by the 'search for a new paradigm' (Habermas 1996: 390). That is as far Habermas goes empirically. When he develops the idea of a proceduralist paradigm of law, the historical analysis is replaced by normative theory. However, Habermas is not a utopian thinker in the negative sense of the word. His normative theory takes its point of departure in the dysfunctions of the social-welfare paradigm. ${ }^{6}$ There is without doubt some kind of evolutionism in play here. It is important to see that the earlier paradigm does not simply disappear in this development, but is rather embedded and relativized in a new context and thus, so to say, elevated to a 'higher level' (Habermas 1996: 410). The social-welfare paradigm should be seen as a solution to the dysfunctions of the liberal paradigm. The proceduralist paradigm, in turn, should be regarded as a suggestion about how the dysfunctions of the social-welfare paradigm can be escaped, without falling back into the liberal paradigm and its problems.

One might wonder why Habermas takes his point of departure in law. One answer is that he situates his normative theory empirically through the medium of law. A related answer is that law is more than just legal 
paragraphs. Habermas disagrees with legal realism. Laws are part of a paradigm of law, and every paradigm contains a constitutional part and involves an implicit image of society. Ordinary legislation could never work without a 'social ideal' or 'social vision' more or less taken for granted. Legislation within the liberal or formal paradigm of law was, according to Habermas, embedded in the hegemony of civil rights and the image of a 'private law society' (Privatrechtgesellschaft). By means of a 'materialization' of law this paradigm was transformed, which led to the hegemony of social rights and the rise of the image of a mass democracy constituted as a social-welfare state ('sozialstaatliche Massendemokratie'). Habermas' theory of a procedural paradigm of law, in turn, privileges political rights and envisions a society in which general deliberative participation in political life plays a crucial role.

I find it helpful to make use of Marshall's (1964) well-known distinction between civil, political, and social citizenship in my attempt to explicate the difference between these three paradigms of law. ${ }^{7}$ It was during the liberal epoch that the fundamental modern institutions of rule of law and democracy were institutionalized. However, during this epoch civil citizenship was privileged at the expense of social and political citizenship. Political rights were subordinated to civil rights and, thus, to a great extent limited to the bourgeoisie. Thus, the democracy of the $19^{\text {th }}$ century was very elitist. A majority of the people was excluded. To be sure, the civil rights to freedom, life, and property include all citizens, but they are formal rights. In a pure market society, freedom and life are completely dependent on property. The general formal right to property does not automatically lead to material prosperity and freedom for everyone. This is the core of the dysfunctions of the liberal model. The modern person emancipated herself or himself from compulsory public faith, fixed conventions, a rigid hierarchical social order, feudal privileges, and arbitrary despotic rule, but at the same time subjected her or his newly-won political freedom and material well-being to natural and social chance and the cold logic of the market. The consequence was a crude classed society and a conflict between capital and labour that became explosive. Such a society was only possible as long as pre-modern traditions and convictions still could take the edge off class conflict. Thus, during the liberal epoch of modernity, citizenship was too under-developed and exclusive to be able to secure legitimacy for social institutions in a purely modern way. ${ }^{8}$

As the market logic continued to melt the once-so-solid pre-modern convictions to 'thin air' (Marx), the dysfunctions of the limited liberal kind of citizenship threatened modernity as such. This threat was overcome through the transition to the welfare paradigm of law. ${ }^{9}$ This paradigm involved, on the one hand, a kind of political citizenship that was separated from property, and thus radically extended. On the other hand, it involved a materialization of civil rights, that is the establishment of social rights. Every citizen now acquired the right to a minimum material standard (and to education). ${ }^{10}$ These social rights were seen as conditions for the realization of civil and political rights. Social rights became fundamental, and the state transformed itself into a welfare state in order to administer those rights. 
However, at the same moment as this second paradigm of law rose to hegemony another dark form of the dialectic of freedom began to affect modern life. In the welfare-state society the means (social citizenship) tended to override the goals (civil and political citizenship) rather than support them. The means tacitly tended to be transformed into goals. The political and social inclusion of the masses went hand in hand with the decline of the public sphere (Habermas 1989). More and more people obtained political rights, but only at the price of these rights' growing in significance. The public sphere declined, and political autonomy was, for most people, reduced to voting at general elections. Democracy in this second epoch of modernity became a representative democracy closely connected to a large and powerful administrative bureaucracy, that in turn was more or less disconnected from the weak public sphere. ${ }^{11}$ In practice, it was a paternalistic 'expertocracy'. The administration of the social rights was in the hands of experts who- on the basis of a fundamentalist belief in science and with the help of politicians and welfare bureaucrats - gave themselves the right to interpret the true needs of the people. The welfare-state society and the era of social engineering were two sides of the same coin. The welfare bureaucracy colonized the public sphere. The citizen was in practice transformed into a client (Habermas 1987: 301-373).

This second attempt to realize the modern idea of public autonomy through the rule of law and democracy tends in the end, although in another way than the first attempt, to lead to its opposite. Habermas does not oppose the quantitative expansion of political citizenship. Nor does he reject the importance of social rights for the realization of civil and political freedom. Rather, he points at the unintended consequences of the priority of social rights in the social-welfare paradigm. In the end, the institutions that are meant to realize freedom tend to lose their legitimacy. Today, this is called the crisis of democracy. This crisis - which actually is not a crisis of democracy as such but only of a pure representative democracy - threatens modern society. Its cement tends to dissolve. A new paradigm of law is needed to overcome the dysfunctions of the welfare-state society. ${ }^{12}$ This is why the idea of a more participatory kind of democracy is not an empty hope, but rather a necessary solution to the crisis of contemporary democracy.

Habermas argues that the social-welfare paradigm - in contrast to common political sense-is actually too closely connected to the liberal paradigm. ' $[\mathrm{B}]$ oth paradigms share the productivist image of a capitalist industrial society' (Habermas 1996: 407). The liberal paradigm is based on the idea that the state only should protect the formal right to freedom and leave the realization of freedom to the logic of the market; the social-welfare paradigm assumes that a general realization is impossible if the welfare-state bureaucracy does not 'tame' the market. However, '[b] oth views lose sight of the internal relation between private and political autonomy' (Habermas 1996: 408). Both paradigms - and this claim is crucial—are focused on the citizen as the 'addressee' of law rather than as its 'author'. In both cases, the politics of rights is something more or less given, either as something 'natural' which is only to be protected by the state, or as something worked out over the heads of ordinary citizens by experts and administered by a political 
system. In both cases, political autonomy is only secondary. Habermas' intention with his theoretical construction of a third paradigm of law is to strengthen the citizen as the author of law, that is to strengthen the political aspect of citizenship. Only in that way can the modern institutions of rule of law and democracy liberate themselves from the dysfunctions of the previous paradigms and regain legitimacy. Only then is a modern society, under present social circumstances, possible in the long run. The image of society that the third paradigm of law presupposes is one in which politics has its foundation in a public sphere of political deliberation, which is relatively free from both the state and the market. ${ }^{13}$ Thus, the historical argument says not only that the normative foundations of modern society today are in a period of transition rather than consolidation. It also says that there is a certain social logic in this transformation which points in a certain direction. I now turn to the philosophical argument for the proceduralist paradigm of law.

\section{Democracy according to Habermas}

I explicate Habermas' normative theory of law and democracy in five steps. The first step will be to explain his understanding of the relation between private and public autonomy. In the second step, the focus will be on the crucial significance of discourse. Thirdly, I will discuss the relation between the state and the public sphere and the mediating role that law has in this relation. The fourth step concerns the distinction between three forms of political discourse. The last step will be to take a look at Habermas' use of the concept 'political culture'. Figure 1 presents the inter-dependence of these crucial aspects of Habermas' theory of democracy.
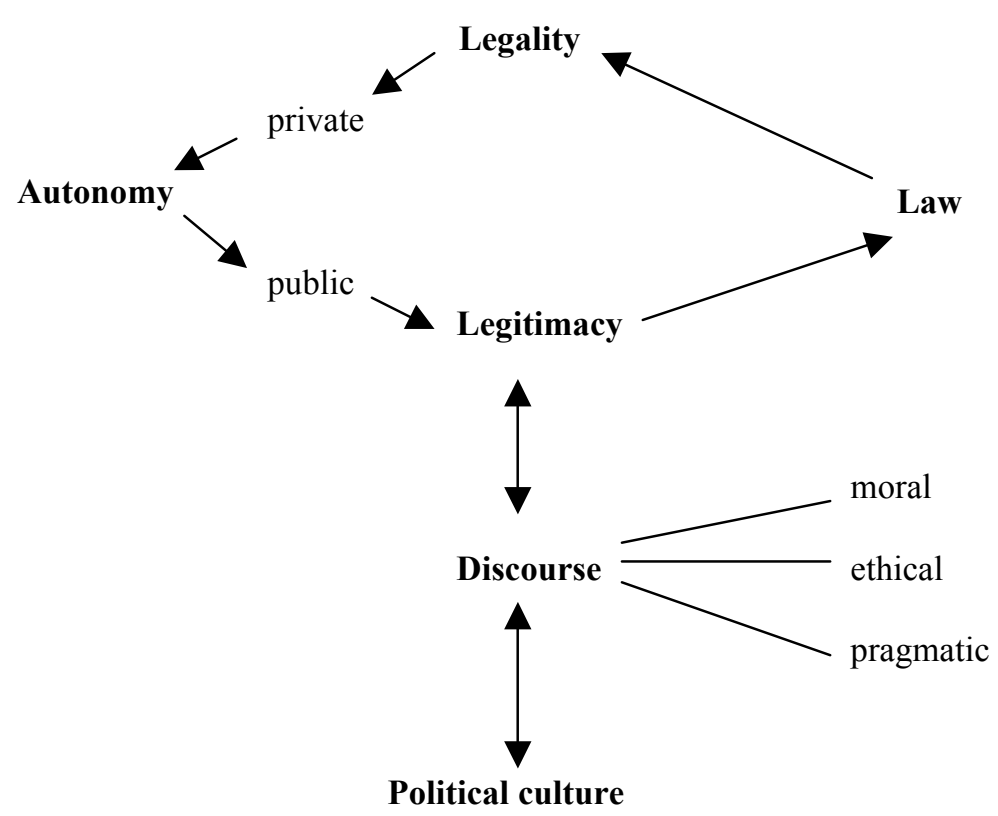

Figure 1. Democracy according to Habermas. 


\section{Private and public autonomy}

Freedom, or autonomy, plays a crucial role in all normative conceptions of modern society (Taylor 1989). A founding idea of modernity in a normative sense is that everybody has a right to freedom. However, and not surprisingly, this normative idea can be understood in many different ways. Classic liberal political theory understood freedom in an individualistic and negative way. ${ }^{14}$ Thus, liberals generally stand up and fight for the idea of the individual person's freedom from others, from the state, freedom to do whatever one wants without any intervention of others, that is private autonomy. However, even the founder of liberalism-Hobbes (1968) - saw that this could not be the whole story. There is at least one limitation to the right to freedom. One does not have the right to undermine the freedom of the other. An unlimited right to private freedom would put people back in the state of nature - the war of every one against every one - and in the end nullify everybody's freedom. Thus, something is needed that - so to say-protects the right to freedom from itself. Hobbes's solution was a sovereign with absolute power. Today, popular sovereignty and the rule of law have taken over that function. However, this solution is not the end of the discussion but rather marks the beginning of political debate under modern conditions. The crucial problem of modern politics is how to understand the relationship between the freedom of one and the freedom of the other, that is the freedom of all. How should this relationship be conceptualized and how should it be institutionalized?

In the history of ideas and of politics these two forms of freedom have often stood in opposition to each other. ${ }^{15}$ The freedom of the individual has, for instance, been conceptualized as 'human rights', while the freedom of all has been conceptualized as 'democracy'. It is in that context that Habermas uses the terms 'private' and 'public autonomy'. The debate between the advocates of a liberal model and the advocates of a welfarestate model is another example of how to understand the political relation between one and the other. The long-standing political discussion about political individualism and collectivism also has its root in this problematic relationship.

In his theory of democracy (see figure 1), Habermas argues that there actually is no conflict between private and public autonomy. Individual human rights and democracy presuppose each other. To understand freedom first and foremost as negative and private-as liberals tend to do-is actually a misunderstanding of freedom. Habermas (1996: 88) quotes Frank Michelman who claims that a right actually 'is a relationship and a social practice ... a form of social co-operation'. Rights-including the right to freedom - should not be misunderstood in an atomistic or individualistic way. Rights actually tell us citizens how we should organize our common life. When we understand the right to freedom in this 'intersubjective' (p. 88) way, it becomes clear that freedom is not only negative and private, it is also positive and public. The meaning of freedom is connected to what we do with our freedom in relation to the other.

How the one relates to the other is not the concern of either the one or the other, but of both together. The norms that regulate their relations 
are public. To talk about the right to freedom in this case means the right of all to participate on equal terms in the decisions of how the laws that regulate a common life should be formulated. However, my argument to this point should not be misunderstood as an argument for political collectivism. Habermas tries to find a route between or beyond individualism and collectivism. The right to take part in the regulation of our common life - that is our political right - is an individual right, that is a right that belongs to each one of us. Democracy presupposes the existence of individual rights. Popular sovereignty should neither be understood in an atomistic nor a holistic, but in an inter-subjective fashion. "We the people' cannot be understood as a totality with one single will. Demos must be understood in a pluralist way, as composed of different and individualized persons with individual rights. Each and everyone has the right to participate in political decisions. The will of the people is the result of a public discourse. Each citizen must have the right to private autonomy in order to have public autonomy, and vice versa. ${ }^{16}$ Privacy in this context means, first and foremost, the right to say: 'No, I do not agree'. On the basis of such an internal relation between human rights and popular sovereignty, we avoid both the risk of tyrannical majorities and of social disintegration.

\section{Discourse}

The only way that the public autonomy of citizens can be made possible is through individual political rights. These rights do not merely say that every citizen has the right to vote on who is going to represent him or her in public matters. Representative democracy is one specific, and more or less contingent, way in which political rights have been institutionalized. More basically, political rights say that every citizen has the right to participate in a public discourse. In order to make each citizen's public autonomy possible the discourse must follow certain procedures. Habermas (1996: 107) talks about the discourse principle: 'Just those norms of action are valid to which all possibly affected could agree as participants in rational discourses'.

This discourse principle is the normative foundation of democracy in Habermas' sense (see figure 1). If it is followed, each citizen can participate in public affairs on equal terms. Rationality here means that consensus must only be reached on the grounds of the better argument. Thus, it excludes every form of violence, threat, and external influence, that is it excludes the right of the stronger or the more powerful to prevail. On this point, the liberal idea of negative freedom is preserved 'on a higher level' in Habermas' theory. People must respect the integrity and the privacy of the person. The person is himself or herself, so to say a kind of private room, in which the pros and cons of arguments that circulate around in the public sphere are weighed. ${ }^{17}$ The person has the right to say 'No, I do not agree'. Only a consensus based on conviction is strong enough in a modern world. Norms can, in the last instance, be considered as legitimate only if the discourseprinciple is followed. Thus, the foundation of democracy is the procedures 
that regulate political discourses. The discourse-principle says nothing substantial. Democratic constitutions and declarations of human rights must for instance allow discussions, new interpretations, and changes on the ground of such procedures if they are to gain or keep legitimacy. This is Habermas' 'proceduralist paradigm of law'.

Because of its procedural character, the discourse principle legitimates itself. People cannot argue against this principle without making use of it, and thus creating what Habermas' close colleague, Apel (1987) calls a 'performative contradiction', that is people contradict what they say in what they do if they argue against this principle. However, for Habermas, in contrast to Apel, this philosophical claim of self-justification only works under certain social conditions. It presupposes the fundamental modern values of individuality and of non-violent solutions of conflicts. ${ }^{18}$ These deep convictions are the 'sacred' values of the modern world (Collins 1988: 252). If they are rejected, then the discourse principle would fall.

These modern pre-conditions should not be confused with Western culture. Today modernity is, according to Habermas (1998a: 163), a global condition and embraces different cultures:

Whether we evaluate this modern starting-point one way or another, they confront us today with a fact that leaves us no choice and thus neither requires, nor is capable of, a retrospective justification. ${ }^{19}$

Here, Habermas reveals his pragmatist heritage. Philosophy and science are in the end instruments to solve social problems. He is not interested in what Charles S. Peirce called 'paper doubts'. To give up the values of modernity would lead secularized societies into a state of nature. In practice, however, most people do not always act in accordance with the social logic of private and public autonomy. That is one reason why the discourse principle must be connected to the rule of law. I will now turn to this issue.

\section{Law}

In Habermas' theory of democracy discourse or deliberation - to use today a more popular term for the same thing-is not everything. Deliberation has its limits. The basic institution of deliberation, the public sphere, must be distinguished from not only the market but also the state. With this claim, Habermas is not arguing that the state has no role to play in a fully democratic society. Rather he is saying that the logic of democracy is not to be reduced to that of the state, and thus criticizes a state-centred understanding of democracy (Habermas 1996) using the distinction made in the second volume of Theory of Communicative Action between 'system' and 'life-world'.

Thus, as I indicated above, the logics of the state and the market are actually closer to one another than to the logic of deliberation. In both the political and the economic systems, actors adapt themselves strategically to the social logic of systems, that is to the impersonal codes of administrative power and money. Action in the public sphere is regulated by the communicative logic of the life-world. However against the republican view, Habermas stresses that, in a modern society, politics cannot only be related 
to life-world. Modern society is so complex that the communicative abilities of citizens would be overstrained if systems did not take over some tasks of social reproduction.

In other words, democracy cannot be founded on the discourse principle alone. Modern democracy pre-supposes that the discourse principle is connected with law, that is that the public sphere is connected with the state (the political or administrative system). In this way, Habermas (1996: 108, 121-122) distinguishes the discourse principle and what he calls the 'principle of democracy'. Another way of putting this is that modern democracy is a combination of legitimacy and legality (see figure 1).

Thus, Habermas is not a republican who believes that the only true form of democracy is the ancient Greek one, a pure participatory democracy. In the modern world any attempt to replace completely system logic with communicative logic would soon be defeated in a way that is close to what Roberto Michels meant with his well-known 'iron law of oligarchy' and what Max Weber meant when he talked about the bureaucratization of political parties.

One important consequence of this claim is that the deliberative core of democracy is to be found outside the institutions normally today called 'political' (Habermas 1999b: 330). The public sphere is composed of social movements, intellectual debates on political issues everywhere, the parliament of the streets, etc. Citizens can influence the public sphere through deliberative participation, whereas they can influence the political system only indirectly by voting.

This indirect kind of influence is possible because law has two sides. Law can and must have both legitimacy and legality. It can and must have both symbolic validity and power. ${ }^{20}$ Law can, thus, mediate between the public sphere of the life-world and the political system. If laws lose legitimacy, people will in the end not follow them. On the other hand, law reduces the idealistic character of the discourse principle. Let me just mention a couple of examples of how this is done.

The transformation of the discourse principle to a principle of democracy involves constraint in both time and space. 'Everybody' is limited to a particular political community, for instance a nation. ${ }^{21}$ The time limit means that ongoing deliberation in the public sphere of what is right has to be interrupted. Now and then we, as citizens, have to come to a decision. It is at this moment that we vote and-through the political system-make the will of the majority a law that everybody must follow. This does not mean that everybody has to agree that the law is right; it only means that everybody has to follow the law. Deliberations over the validity of that law can start over at any time in the public sphere, and those who disagree with the law can hope to convince so many with their arguments that at the next voting day they will be in majority. Thus, the discourse principle must be at work if the laws that are the outcome of this political procedure are to have legitimacy. If everybody in a particular community does not have the opportunity to participate, and if violence and external force of some kind influences the vote and disturb the time-limited discourse, then the law in question will lose in legitimacy. This process gives the political meaning of proceduralism: laws are based on democratic procedures, 
which have to be legitimate. It is in this proceduralistic way that democracy is based on the discourse principle.

The strong demand of convincing by way of reason found in the discourse principle is thus, in a political context, moderated in at least three ways. First, democracy has, to this point, always been limited to a particular community. Secondly, not everybody in such communities needs to be convinced about the validity of the content of the law. It is enough that everybody is convinced about the validity of the procedures that produced that law, which includes the time-limited validity of every law. Thirdly, the legitimacy of the law is supported by its legality. Even if people believe that a law is legitimate in a substantial or procedural sense, they could be tempted to break it. Behind the legality of a law stands the power of the state, and in the last instance its monopoly of violence. ${ }^{22}$

\section{Three forms of political discourse}

Habermas (1993: 1-17) discerns three forms of practical discourse: moral, ethical, and pragmatic (see figure 1). Each form must follow the discourse principle, but the issues that are deliberated upon in the three discourseforms are different in character and scope. A good argument in one discourse can be irrelevant in another; those who are affected by the issue under discussion are-at least in part-different in each of the discourses (Habermas 1996: 108).

Habermas distinguishes between self-realization and self-determination in his effort to make clear the difference between ethical and moral discourse. He also uses the distinction between the concepts 'authenticity' and 'autonomy' for the same purpose. Ethics is about questions of identity and, in a political context, it is most often about collective identities. Like modern life in general our identities have become 'post-traditional' (Habermas 1996: 97): we must realize ourselves under conditions of contingency, pluralism, and reflexivity. In an ethical discourse, we try to find out who we are and who we want to be. The focus lies on 'we' in contrast to 'them'. An ethical discourse does not include everybody in the sense of the whole of humanity, or even a national community, but only those who share the same traditions and strong evaluations (Habermas 1996: 108). The question is how a community can renew its traditions in an ever-changing world, and preserve in some sense a common identity.

By contrast, a moral discourse includes in principle humanity as a whole. It not only includes 'us', but also strangers. Habermas (1998a: 164) talks in this context about 'an abstract form of civic solidarity among strangers who want to remain strangers'. The question here is how a person should behave towards someone who has other values and another identity. In a pragmatic discourse groups with different interests and values try to reach fair compromises. The parties in such a discourse do not-in contrast to an ethical discourse - need to agree on what is good (the validity of values) and-in contrast to a moral discourse - on what is right (justice). Rather they need to find how different parties can best satisfy their conflicting interests. These discourses can only be analytically differentiated. In real political life a 
specific conflict often has to be deliberated upon in all three of these aspects. But in such situations it becomes important that these aspects not be confused with one another. ${ }^{23}$

\section{Political culture}

Like Weber-although with a somewhat different meaning-Habermas claims that society is undergoing a process of rationalization. I have already discussed how he understands this transformation of modern society. One aspect is that certain tasks of social reproduction are taken over by systems. Thus, Habermas points to the fact that the material reproduction of society is more and more regulated according to the codes of money and administrative power. Furthermore, the life-world is becoming more and more 'post-traditional' in character. People's beliefs become more and more differentiated, individualized, contingent, and reflexive. In traditional societies beliefs, norms, and values were often inherited from one generation to the next; they had some kind of immediate validity. Today, people must deliberate on their validity. In one sense, this post-traditional character of society is a social condition of democracy. Citizens cannot be autonomous if they do not reflect upon what is true, right, good, and fair (and even beautiful), that is if they do not use their reason.

However, Habermas (1996: 113) argues that reason, in contrast to tradition and habit, does not immediately motivate action. Reason is inherently critical, suspicious, and calls everything in question. This is a very important feature of the democratic life-form, but it creates a gap between judgements and actions. Reason as an action-motivating force is weak compared to traditions and habits. As we all know, we often act differently than we know we should. Thus, recently Habermas (2003: 7) has placed an emphasis on the importance of not commiting the 'intellectualistic misunderstanding', and quotes Kierkegaard's (1980) gloomy statement in The Sickness Unto Death: 'It is tragic-comic to see that all this knowledge and understanding exercises no power at all over men's life'.

In a democratic society law supports reason. It bridges the gap between reason and action. However, this seems not to be enough. To avoid Kierkegaard's conclusion, Habermas (1996: 98-99)—through the back doorreintroduces the significance of traditions and habits in a modern world. $\mathrm{He}$ seems to think-without really explaining their difference from pre-modern traditions - that there is such a thing as modern traditions. He writes that good reasons are dependent on 'socialization processes' and, thus, must in some way be internalized in the 'personality system' (p. 114). In another place he writes that democracy is dependent on a population 'accustomed to freedom' (p. 130).

Here, Habermas seems to be saying that democracy needs democratic traditions. Democracy must belong to - to use the title of book by Bellah et al. (1985) - 'the habits of the heart'. In this context, Habermas' wellknown concept of 'constitutional patriotism' can be understood. Reason and law must be supplemented by a 'political culture' in the sense of ethos or Sittlichkeit, that is it must be supplemented by a non-reflexive democratic 
way of life (see figure 1). The discourse principle must become a part of our identity.

Let me now conclude this section of the paper. I have claimed that the social integration of a modern society depends on some kind of democratic foundation. I have further tried to show that the meaning of democracy has changed during the history of modernity and that there is some kind of weak social logic built into this normative evolution. Finally, I left the functionalistic perspective and argued normatively that Habermas' theory of deliberative democracy provides a better normative foundation for contemporary, modern society than the liberal, the welfare-state, and the republican versions of democracy. The functionalistic and the normative parts of the argumentation are interdependent. Criticism of Habermas' theory of democracy as utopian can be rejected if it can be shown that the normative part is supported by an analysis of the specific dysfunctions of earlier paradigms of law and democracy.

I will connect these arguments with what has actually happened in a specific case, that is the case of educational policy in Sweden during the $20^{\text {th }}$ century. In that way, I can further examine Habermas' general theory historically and investigate its relevance in an educational context.

\section{Normative transformation of Swedish educational policy}

Englund (1986) has developed a theory about different 'educational conceptions', based on an analysis of the emergence and development of citizenship education in Sweden during the $20^{\text {th }}$ century. He uses educational policy documents as empirical material in a similar way to Habermas' use of law in Between Facts and Norms. ${ }^{24}$ 'The central principles of each conception concern the perspective in which education is placed (its societal function) and the type of society for which it prepares individual citizens' (Englund 1986: 254). Thus, the different conceptions of education mirror the different epochs of the Swedish $20^{\text {th }}$-century society-just as in Habermas' theory the different paradigms of law mirror different epochs of modern society in general.

Using this method, Englund identifies three educational conceptions: the 'patriarchal', the 'scientific-rational', and the 'democratic'. These are in turn understood as the results of three 'waves' of educational reforms. The first wave occurred ' $[\mathrm{f}]$ rom the end of the $19^{\text {th }}$ century until the school reform of 1927', the second '[f] rom the closing years of the Second World War to the introduction of 9-year comprehensive education in 1962', and the third '[f]rom the late 1960s to the present day' (Englund 1989: 35). However, just as in Habermas' theory of law, the third conception has a different character from the first two. It is, to a high degree, a normative construction rather than an empirical description of a historical epoch (Englund 1986: 255, 1989: 37). Thus, the third wave has not (yet) resulted in a conception which regulates Swedish education.

These three conceptions seem at first sight to correspond with Habermas' three paradigms of law. However, in a closer look, it is more complicated. Thus, the correspondence between Englund's and Habermas' concepts of democracy has only become more and more apparent over the 
years. Today, Englund explicitly uses Habermas' concept of discourse to develop the normative idea of a third conception of education (e.g. Englund 2002). Habermas' idea of communicative rationality, thus, becomes a source of inspiration not only for the educational methods of the democratic conception but also for its content, that is the type of citizenship this conception aims at. The relation between the third conception in Englund's theory and the deliberative part of the third paradigm in Habermas' theory overlaps almost totally, and, therefore, I will only make brief passing comments on that relation. I turn instead to the other two conceptions.

The first, early- $20^{\text {th }}$-century wave of educational reform 'brought with it a crucial breakthrough for educational policies based on liberal and social democratic ideals', that is reform 'in terms of the length of compulsory school attendance and curriculum content which could potentially impart citizenship skills' (Englund 1986: 263). Englund discusses in this context the 'secularized content of a kind preparing pupils for citizenship ...' (p. 262). However, he also stresses that this first 'cycle of reform could not break the conservative hegemony in the educational sphere' (p. 264). It was still, to a high degree, a kind of education which taught 'subservience to God and one's country' (Englund 1995: 57; my translation). This early-20 ${ }^{\text {th }}$-century educational conception was hierarchical and elitist, both in method and in content, and tended to reproduce pre-modern power relations.

With the second, post-second world war wave of reform this conservative hegemony was broken. 'At the basis of this new conception there lay a positive assessment of the value of contemporary science and technology in the service of welfare society' (Englund 1986: 267). The conception 'held that the experts were to plan rationally for and on behalf of the rest of the population' (p. 267). Englund uses in this context a Weberian terminology: the educational policy transformation was a shift from 'value rationality' (related to God and Nation) to 'means-ends rationality'. The overarching political ambition of economic growth and the demands from the labour market dominated educational policy:

The dominant notion of the citizen's role in this society was no longer ... that citizens should sustain and help to shape democracy; instead, citizens were to be a labour resource for building up the prosperity of a society embarked on economic growth' (Englund 1986: 269). ${ }^{25}$

This closer look reveals that there are both similarities and differences between Habermas' and Englund's conceptions of political change. The most obvious difference is that, whereas Habermas sees the first paradigm of law as liberal, Englund emphasizes the significance of conservatism for the first conception of education. However, Englund's description of the second and third conceptions resembles Habermas' description of the second and third paradigm of law in many ways. Thus, when Englund compares the second and the third conceptions, as in the quotation above, it seems to be another way of saying that citizens in the second conception are the addressees of law rather than its authors. Furthermore, like Habermas, Englund links the second conception to a welfare society and to the crucial role of scientific expertise. Such similarities in the second and third conception/ paradigm indicate the relevance of Habermas' theory in an educational 
context. The more difficult question, however, is the significance of the difference between Habermas and Englund in their understandings of the first conception/paradigm. ${ }^{26}$

Should Englund's empirical findings about the hegemony of conservatism in the first conception lead to the conclusion that Habermas is wrong in talking about a liberal paradigm, at least in the context of Swedish educational policy? Perhaps Englund's findings mirror the particularity of the Swedish case, and thus supports the common view that modernity came relatively late to Sweden and, when it came, it quickly became a socialwelfare state-based kind of modernity. If that were true, it would probably mean that Habermas' theory of normative transformation in general could be relevant only with major reservations to the history of Swedish educational policy. That, in turn, could raise questions about whether an abstract and general theory, like that of Habermas, is useful to understand such specific empirical events as national educational policies and their transformation.

However, there is a difference between Habermas' and Englund's points of departure which make a direct comparison difficult. If this difference is clarified, then - as I will show-the outcome of the comparison changes. I turn now to their different points of departure.

Both Englund (1986: 312) and Habermas develop their conceptions/ paradigms in terms of ideal types. However, whereas Habermas' starting point is a basic concept of modernity, Englund's first conception cuts through the distinction between traditional and modern society. The common modernity of Habermas' three paradigms is that they all are founded on notions of individual rights (civil, social, or political). The common feature of Englund's three conceptions seems to be the existence of a compulsory education of some length for all, and in each case this involves - to some degree and in some sense-a secularized idea of citizenship. Englund's theoretical strategy for differentiating the first from the second and third conceptions is to point to the overwhelming conservative influences on the first conception. From Habermas' perspective such influences are of only secondary interest in that they are remnants from a pre-modern stage.

How might it be fruitful to take another look at the specificity of Englund's first conception from Habermas' modern point of departure? Habermas could be criticized because his perspective tends to lead to a neglect of the influence of some traits on modern politics. The crucial importance of nationalism for modern societies, for instance, can hardly be understood from paradigms based on different individual rights. ${ }^{27}$ On the other hand, I believe that Englund can be criticized for not working out the specific modern aspect of his first conception. If Englund were to ask what kind of secularized idea of citizenship he might find in early- $20^{\text {th }}$ century Swedish educational policy, and in what sense this idea might differ from the ideas of secularized citizenship which regulate the other two conceptions, then Habermas' theory of the first paradigm of law might be useful. ${ }^{28}$ Thus, I would suggest a search for an answer to those questions which focuses on liberal traits, that is on the idea of civil rights. This suggestion in turn implies that it could be fruitful to analyse the transformation of education policy in 
general from the perspective of individual rights in a manner similar to the logic of Habermas' differentiation between the three paradigms of law.

One problem in using such a theoretical perspective on the kind of empirical material that Englund uses for the elaboration of his first conception might be that education in general should be understood as a kind of social right (Marshall 1964, Englund 1989, 1994). A pure civil-right category seems to exclude a public right to education. In a pure 'private-law society' there are no public schools, and education is the responsibility of parents, and thus dependent on their economic, social, and cultural capital. Under such conditions I could not, therefore, for logical reasons, develop a public liberal conception of citizenship education. However, as I suggested in my discussion of Habermas' theory of democracy, freedom in the liberal sense points beyond itself. Everybody has the right to freedom, and the freedom of the one depends on the respect for that freedom from the other. Thus, freedom should not be understood as a purely private good. Everybody must learn not only that they have a right to freedom but also respect for the freedom of the other. In that sense a liberal idea of public citizenship education is plausible.

To find some empirical support for my proposal to use the logic of Habermas' theory of normative transformation to further develop Englund's theory of educational policy, I will now briefly turn to a recent study by Boman (2002). She has also investigated $20^{\text {th }}$-century Swedish educational policy, but - in contrast to Englund who addressed on the content of citizenship education-focused first and foremost on changing ideas about the right of access to education. However, even though Boman has this slightly different focus, it is not far-fetched to presume that her findings also might say something about educational conceptions of citizenship. After all, the right of access to education is - as I have shown - a part of being a citizen.

It is commonly argued that the ideal of equality is as essential to modernity as the ideal of freedom. However, it is wrong simply to see equality as a social-welfare value and freedom as a liberal value. A more complex and useful picture of these values is obtained by turning back to Marshall (1964) and differentiating between civil and social equality or, to put it another way, to the idea that everybody has the same right to civil or social citizenship (Carleheden 1998). Thus, equality should be seen as the other side of freedom. Boman does this, and shows that equality has been a fundamental idea in Swedish educational policy, both in a liberal and in a welfare-state sense. She finds four kinds of equality ideals in Swedish educational policy documents; 'equal right of entry', 'equal opportunity', 'equal treatment', and 'equal result' (Boman 2002: 263-330; my translation). She describes the first kind of equality as 'civil', in Marshall's sense, which in this context means that nobody should be denied entry to an education because of class or sex (Boman 2002: 169). The only criterion of distinction that should be allowed is talent. This is the liberal ideal of equality.

Boman contends that the equality-ideal that prevailed in Swedish educational policy during the first half of the $20^{\text {th }}$ century was 'liberal'. People with different talents should receive different education. The more talented the pupils, the better education they should receive. This does not imply a denial that conservatism significantly influenced early Swedish educational policy. 
Rather, it says that a liberal kind of educational policy, based on an idea of civil citizenship, also played a significant role. The other forms of equality that Boman introduces-'equal opportunity', 'equal treatment', and 'equal result'-became influential only later.

The ideological basis for critique that emerged from the liberal idea of equality was that the actual effect of liberal equality was a new kind of class society where the talented received a better education than others. Freedom for everybody cannot be thought about only in terms of equal civil rights. Thus, it is possible to argue not only that all should have the right to the same education (equal treatment), but that the less-talented, and those with the disadvantaged social conditions, should have the right to a better-in some sense-education than others (equal result). Such a policy shift can be seen as a materialization of liberal rights in the way Habermas understands the shift from the liberal to the social-welfare paradigm of law.

In other words, to follow Boman (2002) is not only to emphasize the liberal component of Englund's first conception, but also to emphasize the value of equality across his periodization of Swedish educational policy. The second educational conception is not only dominated by science and instrumental rationality but also by the value of social equality. It might at first sight seem contradictory to bring a value into a conception characterized by instrumental rationality and value-neutrality. The conception of instrumental rationality and value-neutrality-in its Swedish version-is heavily influenced by the nihilism of the 1950s and 1960s when the idea of the 'death of ideology' flourished among intellectuals. However, the idea was on a deeper level, based on a more or less tacit ideology, which in its socialwelfare version was dominated by the value of social equality (Sigurdson 2000). This is hardly surprising. Every modern political system needs some degree of legitimacy, which - in the last instance-must have some kind of support in the public sphere. ${ }^{29}$

Boman's study gives some support not only to the idea of a liberal educational conception but also to the proposal to use Habermas' theory of normative transformation in general in order to understand changes of educational policy in modern society. Taken together, Englund's (1986) and Boman's (2002) studies seems to confirm Habermas' theory of the dysfunctionality of both the first and second paradigm of law in an educational context.

\section{Conclusion}

I have argued in several ways that contemporary educational policy needs a deliberative democratic foundation. I have done so sociologically, historically, and philosophically with the help of Habermas' theory of law and democracy. I have also tried to support that general argument with a more specific discussion of Englund's and Boman's studies of $20^{\text {th }}$-century Swedish educational policy. My claim has been that these studies-at least in their combination - support the idea of using Habermas' theory of normative transformation in an educational context. However, so far the idea of both a procedural paradigm of law and an educational conception of democracy 
has largely remained a normative construction. I will conclude this paper by trying to give a very tentative answer to the question of whether there are any signs of a third paradigm of law and democracy and a third educational conception in contemporary Swedish politics. From the perspective presented here, I suspect that the 'crisis of democracy', which is so much debated in contemporary Sweden, could be explained by the declining legitimacy of the second paradigm. ${ }^{30}$ That might, according to Habermas' weak evolutionism, open up space for democratization in a deliberative sense. Before I turn to that question, I will comment on what such democratization would involve normatively in an educational context.

Democratic values are not something that 'naturally' grow in children, or something that can be altogether left to parents. Democratic socialization is a public matter and a public responsibility. From a sociological or functional perspective, democratic socialization should be seen as a fundamental condition for the survival of modern societies. From a normative perspective, it should be seen as a condition for freedom and equality. Thus, schools should make citizenship education, in a deliberative democratic sense, a fundamental task.

The perspective that has been developed here implies a rejection of value-relativism. Deliberation does not simply mean that everybody has the right to express their opinions and to act as they themselves see fit. Deliberation does not imply that Feyerabend's (1993) principle 'anything goes' should be taken into the classroom. That would be to reduce democracy to the liberal idea of negative freedom. ${ }^{31}$ Rather, the crucial point is that pupils should learn the art of argumentation - and argumentation is not only more than expressing an opinion and more than communication in the meaning of a dialogue. Deliberation as argumentation is discursive. ${ }^{32}$ To learn how to become a democratic citizen is not only to learn to be tolerant and respectful of the otherness of the other. It is not only to learn to listen to or to be moved and influenced by otherness, but also to learn how to co-operate, to coordinate one's action with the other, to solve conflicts without violence or any form of external force. It is to learn how to convince and be convinced by the 'forceless force of the better argument' (Habermas 1971: 137; my translation), which includes both the ability to articulate one's deepest beliefs in a convincing way and to call them into question. Further, it is about creating collective and personal identities through deliberation.

By emphasizing the significance of political culture, democratic citizens will learn to make participation in the public sphere a virtue. ${ }^{33}$ At the same time they have learned the meaning of the rule of law and how that is connected with the art of deliberation. They have learned to accept that their own views - even after long and rational discussions with their opponentsdo not become law and also, in spite of that, to continue to argue for their views. Obedience to laws on a social level is a virtue of democracy as much as criticism of laws on a cultural level. A democratic citizen recognizes the difference. $^{34}$

I have also demonstrated the significance of the difference between particular kinds of practical discourses and of not confusing their special logics. It is, for instance, essential in a multicultural society and an increasingly global world not to confuse 'our' particular values and collective 
identity (ethics) with the general norms that should regulate that society or the world (morality). ${ }^{35}$

I end with a very tentative attempt to say something about the actual status of this normative idea in the case of Sweden. In Sweden, as in many other countries, neo-liberalism dominated the political agenda in the 1990s. The growth in number of private schools can be seen as the most obvious part of this development in an educational context. This development might threaten the idea of education as a social right and seems, at first sight, to mark the return to a policy that views education as a private good (Englund 1994). The Swedish Commission for the Study of Power and Democracy (Maktutredningen SOU 1990: 44) played an important ideological role in this political transformation in the Swedish case.

In their directives to the Commission, the Social Democratic government could still in 1985 'once and for all' take the ideals of democracy 'for granted' (SOU 1990: 44, 412). Thus, it was not these ideals as such that the Commission was meant to investigate but the social conditions for their realization. Thus, the social-welfare paradigm of law and democracy seemed at that time still unthreatened. However, something happened during the 5 years that went by between the writing of these directives and the publication of the final report of the Commission. The members of the Commission revolted against their directives and discussed not only the realization of democracy but also its ideals. They contrasted what they called a 'societycentred' against an 'individual-centred' democratic ideal. For the sake of simplicity, these ideals in Habermas' terms may be understood as a socialwelfare paradigm in contrast to a liberal paradigm of law and democracy. The Commission (SOU 1990: 14) criticized the fact that the former had for too long dominated Swedish politics and argued for a better balance between the two ideals.

This Commission was without doubt one of the first more important intellectual signs that the social-welfare paradigm in Sweden had begun to lose its political hegemony. Another example was the intensive debate at the end of the 1990s about the remarkably high number of sterilizations (of mostly women on sometimes purely moralist and racist grounds) which took place when the Social Democratic party was in office. Of course, structural social forces played a crucial role for this political transformation. ${ }^{36} \mathrm{My}$ claim, however, is that this development should not be seen as signs of a return of the liberal paradigm of law. Neo-liberalism is not the future, but rather a sign of political crisis. It characterizes a situation in which the old paradigm has lost legitimacy without a new one yet having been established. To use Habermas' words again, there is a search for a new paradigm of law. Wagner (1994) calls this period 'the second crisis of modernity' (Carleheden 2001).

Political developments in Sweden during the first few years of the $21^{\text {st }}$ century seems to give some support to the claim that this search is going in the direction of deliberative democracy. During these years several important official political documents have been published which seem to understand some kind of participatory and deliberative democratic political construction as the solution to the present political crisis. I am here, for instance, thinking about the final report of the commission of democracy (SOU 2000: 1), the commission of municipal democracy (SOU 2001: 48) 
and the government bill on democracy (Prop 2001/02: 80). They show that there is today-more or less-a political consensus in the Swedish parliament about this political orientation (Gilljam and Hermansson 2003: 20). Furthermore, in an educational context, the Swedish government agency for school improvement (Skolverket) has published several reports which explicitly support the idea that deliberative democracy should be the normative foundation of education in public schools. ${ }^{37}$ If such documents either mirror a deeper social transformation or can initiate to some extent such a transformation, the present could herald the beginning of a political and educational development, which actually points in the direction of Habermas' and Englund's third paradigm/conception.

\section{Acknowledgement}

An earlier version of this paper was presented at the 2003 annual meeting of the American Educational Research Association, Chicago.

\section{Notes}

1. Compare my discussion of Englund's different conceptions of education in the second part of this paper and that of Boman (2002: 159-390). I take it for granted here that the politics of education and educational praxis correspond to some extent. However, educational praxis is also influenced by social structures (compare, e.g. Bourdieu and Passeron 1990) and by individual intentions. The theoretical perspective of this paper does not exclude such perspectives, but complements them.

2. Habermas' few texts about education are only about higher education, and were written in the 1950s and the 1960s (Habermas 1981), that is before he had developed his most important theories. I will primarily use Faktizität und Geltung (1992). The somewhat misleading English title is Between Facts and Norms (1996). I will refer to English translations of Habermas when possible.

3. I am not saying that institutionalized norms are the only, or even the most important, social facts needed to understand social transformation. However, I agree with Habermas when he claims that normative structures 'do develop in reaction to changes in the domain of instrumental and strategic action; but in doing so they follow their own logic' (Habermas 1984: 148). It is this normative logic that is of interest in this paper.

4. Habermas only sketches this history. In another context (Carleheden 2001), I have tried to work out such an idea of a history of modernity. That paper forms the background of my interpretation of Habermas on this point.

5. Explicitly, Habermas refers only to the German and American legal traditions, but I believe that this history more or less can be applied to most countries in the Western world. The US has generally been more liberal than European countries (Wagner 1994), but even today the Bush administration is explicitly fighting the New Deal heritage, which shows that the social-welfare paradigm still has influence on that country.

6. This point of departure shows that more than a decade has passed since Habermas wrote Between Facts and Norms. With increased globalization and the escalating 'monetarization' of the world, it is not self-evident that the dysfunctions of the social-welfare paradigm remain the biggest problems. However, as Habermas writes in a later essay: 'One can remain sensitive to the normalizing force of social bureaucracies without closing one's eyes to the shocking price that a reckless monetarization of the life-world would demand' (Habermas 2001: 87).

7. However, compare Habermas' (1996: 77) criticism of Marshall (1964). The most important difference in the context of this paper is that Habermas develops the meaning 
of political citizenship and changes an evolutionary order. Marshall, in accordance with the logic of the social-welfare paradigm, reduces the importance of political citizenship and understands social citizenship as the final, and highest, stage of modern politics. Habermas turns that order around.

8. For that reason conservatism played an important role during the liberal epoch. Compare my discussion of Englund's theory of educational politics in the second part of this paper.

9. This is the functionalistic way of understanding this transformation. From the perspective of action theory the importance of the struggle of the working class should be emphasized. Habermas (1987: 113-197) argues that social theory must use both these perspectives, but he himself has sometimes had the tendency to neglect the importance of social struggle.

10. Social rights should be understood in contrast to charity.

11. Democracy during this epoch can, with Barber (1984), be called 'weak democracy'.

12. The declining legitimacy of the second paradigm of law and democracy has a very complicated history. Nationalism played a constituting role in the establishment of this epoch. Thus, globalization is an important explaining factor of its demise. However, also the ongoing 'rationalization of the life-world', that is the ongoing increase in reflexivity, individualism, and pluralism (Habermas 1987: 145, 1996: 94), tends to come in conflict with representative democracy. Compare also Inglehart's many empirical studies of normative transformation. Inglehart (1997: 79) talks about 'a move away from both traditional authority and state authority' and a 'declining confidence in hierarchical institutions'. Further he talks about a 'diminishing faith in science, technology, and rationality', and about 'self-expression and political participation as things that are valuable in themselves'. He explains this transformation with a general increase in welfare. This explanation implicitly supports Habermas' weak evolutionism.

13. As already mentioned, the other paradigms are assumed to be included in the proceduralist paradigm and thus lifted up to a higher level. However, civil and social rights have a different status in this new paradigm. Social rights are only given a 'relative justification', i.e. they 'are supposed to secure the living conditions necessary for an equal opportunity to utilize private liberties and political civil rights, both of which are justified in absolute terms' (Habermas 1998b: 440). The meaning of social rights and solidarity within a procedural paradigm is, thus, not simply to secure a certain level of material welfare, but to enable all citizens to become autonomous in a political sense.

14. Compare Berlin's (1984) distinction between negative and positive freedom.

15. Compare Habermas' (1996: 99-104) criticism of Kant and Rousseau, and the significance of the different theoretical positions of Nozick and Rawls in contemporary political theory (Erman 2003: 23-42).

16. 'The desired internal relation between human rights and popular sovereignty consists in this: human rights institutionalize the communicative conditions for a reasonable political will-formation. Rights, which make the exercise of popular sovereignty possible, cannot be imposed on this practice like external constraints. To be sure, this claim is immediately plausible only for political rights, that is, the rights of communication and participation; it is not so obvious for the classical human rights that guarantee the citizen's private autonomy' (Habermas 1998a: 160).

17. That does not imply an atomistic anthropology. Rather, Habermas is influenced by Mead and the idea that individual freedom presupposes social interaction. The right way to free oneself from oppressive situations, groups, or persons is to widen one's field of social interaction. The cosmopolitan is free in the sense that she or he can weigh every particular value against other values. The universalization of mind is the route to freedom (see, e.g. Habermas 1999a: 57-58).

18. The principle of non-violence (or bodily integrity) might be redundant. It probably already follows from the principle of the sacred individual. Durkheim (1953: 59) talked about 'the cult of the individual' as typical of the new kind of society that he lived in.

19. In order to see that different modern cultures are possible, Habermas makes four distinctions: First, between social logic and genesis: the fact that modernity has its historical origin in the West does not necessarily reduce the validity of its logic to that culture. Secondly, between law and morality: the social logic of modernity is built on law rather than morality, that is on individual rights rather than on duties and obligations. Thirdly, 
between procedure and substance: the legitimacy of law is based on the discourse principle, that is on a procedure which allows the questioning of all substantive claims, even the discourse principle itself. Fourthly, between morality and ethics, that is between norms and values. I will soon return to this, but none of this hinders the proposition that conceptions of human rights have been and are used ideologically. However, that should not lead a reader to assume 'that the meaning of human rights is exhausted by their misuse' (Habermas 1998a: 169). However, there seems, as far as I can see, a real problem here. Modernity does not exclude private, but what might be called public or constitutional religiosity. It demystifies the absolute validity that public religions presuppose. In this sense, modernity demands the execution of God. This explains the violent resistance from non-modern cultures, that is from fundamentalists. Habermas shares this problem with Rawls (1993) and his theory about an 'overlapping consensus', and 'reasonable comprehensive doctrines'. How should people who adhere to 'unreasonable' doctrines be treated?

20. ' $[\mathrm{L}] \mathrm{aw}$ requires more than mere acceptance; besides demanding that its addressees give it de facto recognition, the law claims to deserve their recognition' (Habermas 1998a: 157).

21 . In this context I skip the very pressing issue of global democracy.

22. Thus, violence does play an important constructive role in a modern society, but only when subordinated to the rule of law and democracy (compare Habermas 1998a: 158).

23. The distinction between morality and ethics would, for instance, be helpful in the contemporary European discussions about women's use of the veil in public schools. In the discussion, moral (equality of women) and ethical (cultural identity and belonging) arguments are often mixed up in an unproductive way.

24. Englund's empirical material is, however, much more extensive than Habermas'.

25. When Englund uses the words 'no longer' in this quotation, he refers to a short period directly after the Second World War when signs of a democratic conception were actually present in Swedish educational policy.

26. Another difference, which I cannot explore here, is that Englund, in contrast to Habermas, does not seem to be influenced by systems theory. Instrumental rather than systemic rationality plays the main role in the second educational conception and none of these forms of rationality seem to play any significant role in the third.

27. Compare my critique of Habermas in Carleheden (2001).

28. Englund $(1986: 318,1989)$ does distinguish between three concepts of democracy in his differentiation between the three educational conceptions, i.e. a 'formal', 'functionalist', and 'normative' concept of democracy. This approach could be interpreted in a way that might lead to a good answer to the question. However, Englund does not really do that himself, and I believe that Habermas' reconstruction of Marshall's differentiation between civil, social, and political citizenship provides a better point of departure.

29. A general faith in science was also an important part of this public support.

30. This debate is about the declining number of people voting in general elections, the declining number of people who are members of political parties, the rising contempt for politicians, etc.

31. Compare Lukes (2003), who takes Robert Frost's accusation that 'a liberal is someone who can't take his own side in an argument' as his starting point. However, according to my claim above, the liberal idea of negative freedom tends to point beyond itself. Thus, perhaps this accusation rather should be directed against the post-modernist.

32. Habermas's concept of communication is, thus, more demanding than Gadamer's or Dewey's. Compare Habermas (1985b).

33. It is uncertain if Habermas would agree. Compare his rather confusing answer to Richard Bernstein in Habermas (1998b: 384-389).

34. The exact line between these two levels is not easy to nail down. Habermas (1985a) allows, for instance, 'civil disobedience' under certain circumstances.

35. Such a confusion prevails, for instance, in present Swedish educational policy, where it is stated that public education should take its point of departure in 'Christian tradition and Western humanism'.

36. Compare note 12 .

37. One of them even explicitly sanctions a Habermasian understanding of democracy (Skolverket 2000). 


\section{References}

Apel, K.-O. (1987) Fallibilismus, Konsenstheorie der Wahrheit und Letztbegründung [Fallibilism, consensus theory of truth and basic validation]. In Forum für Philosophie Bad Homburg (ed.), Philosophie und Begründung [Philosophy and validation] (Frankfurt am Main, Germany: Suhrkamp), 116-211.

Barber, B. R. (1984) Strong Democracy: Participatory Politics for a New Age (Berkeley, CA: University of California Press).

Bellah, R. N., Madsen, R., Sullivan, W. M., Swidler, A. and Tipton, S. M. (eds) (1985) Habits of the Heart: Individualism and Commitment in American Life (Berkeley, CA: University of California Press).

Berlin, I. (1984) Two concepts of liberty. In M. J. Sandel (ed.), Liberalism and its Critics (New York: New York University Press), 15-36.

Boman, Y. (2002) Utbildningspolitik $i$ det andra moderna-Om skolans normativa villkor [Educational policy in second modernity: on the normative conditions of education]. Örebro Studies in Education 4 (Örebro, Sweden: Örebro University).

Bourdieu, P. and Passeron, J.-C. (1990) Reproduction in Education, Society, and Culture, trans. R. Nice (London: Sage).

Carleheden, M. (1998) Politik i det andra moderna [Politics in second modernity]. Häften för kritiska studier, 31(3), 14-34.

Carleheden, M. (2001) Rethinking the epochs of Western modernity. In M. Carleheden and M. H. Jacobsen (eds), The Transformation of Modernity: Aspects of the Past, Present, and the Future of an Era (London: Ashgate), 83-115.

Collins, R. (1988) Theoretical Sociology (San Diego, CA: Harcourt Brace Jovanovich).

Durkheim, E. (1953) Sociology and Philosophy, trans. D. F. Pocock (New York: Free Press).

Englund, T. (1986) Curriculum as a Political Problem: Changing Educational Conceptions with Special Reference to Citizenship Education, Uppsala Studies in Education 25 (Lund, Sweden: Studentlitteratur/Chartwell-Bratt).

Englund, T. (1989) Educational conceptions and citizenship education. In S. J. Ball and S. Larsson (eds), The Struggle for Democratic Education: Equality and Participation in Sweden (New York: Falmer), 32-66.

Englund, T. (1994) Education as a citizenship right-a concept in transition: Sweden related to other Western democracies and political philosophy. Fournal of Curriculum Studies, 26(4), 383-399.

Englund, T. (1995) På väg mot undervisning som det ordnade samtalet? [Towards teaching as an ordered conversation]. In G. Berg, T. Englund and S. Lindblad (eds), Kunskap organisation demokrati [Knowledge organization democracy] (Lund, Sweden: Studentlitteratur), 49-70.

Englund, T. (2002) Utbildning som medborgerlig rättighet-Skilda traditioner och uttolkningsmöjligheter [Education as a citizenship right: Different traditions and possibilities]. Utbildning \& Demokrati, 11(1), 111-120.

Erman, E. (2003) Action and Institution: Contributions to a Discourse Theory of Human Rights. Stockholm Studies in Politics 95 (Stockholm: Stockholm University).

Feyerabend, P. K (1993) Against Method, 3rd edn (London: Verso).

Gilljam, M and Hermansson, J. (2003) Demokratins mekanismer [The mechanisms of democracy] (Malmö, Sweden: Liber).

Habermas, J. (1971) Vorbereitende Bemerkungen zu einer Theorie der kommunikativen Kompetenz [Preparatory notes for a theory of communicative competence]. In J. Habermas and N. Luhmann (eds), Theorie der Gesellschaft oder Sozialtechnologie [Social theory or social technology] (Frankfurt am Main, Germany: Suhrkamp), 101-141.

Habermas, J. (1981) Kleine Politische Schriften I-IV [Minor political essays I-IV] (Frankfurt am Main, Germany: Suhrkamp).

Habermas, J. (1984) Communication and the Evolution of Society, trans. T. McCarthy (Cambridge: Polity Press).

Habermas, J. (1985a) Ziviler Ungehorsam-Testfall für den demokratischen Rechtsstaat [Civil disobedience. Testing the democratic rule of law]. In J. Habermas (ed.), Die Neue Unübersichtlichkeit [The new obscurity] (Frankfurt am Main, Germany: Suhrkamp), 79-99. 
Habermas, J. (1985b) Der Universalitätsanspruch der Hermeneutik. In J. Habermas (ed.), Zur Logik der Sozialwissenschaften [On the logic of the social sciences] (Frankfurt am Main, Germany: Suhrkamp), 331-366.

Habermas, J. (1987) The Theory of Communicative Action, Vol 2: Lifeworld and System: A Critique of Functionalist Reason, trans. T. McCarthy (Boston: Beacon Press).

Habermas, J. (1989) The Structural Transformation of the Public Sphere: An Inquiry Into a Category of Bourgeois Society, trans. T. Burger with the assistance of F. Lawrence (Cambridge, MA: MIT Press).

Habermas, J. (1993) Fustification and Application: Remarks on Discourse Ethics, trans. C. Cronin (Cambridge: Polity Press).

Habermas, J. (1996) Between Facts and Norms: Contributions to a Discourse Theory of Law and Democracy, trans. W. Rehg (Cambridge: Polity Press).

Habermas, J. (1998a) Remarks on legitimation through human rights. Philosophy E Social Criticism, 24(2-3), 157-171.

Habermas, J. (1998b) Reply to symposium participants, Benjamin N. Cardozo School of Law. In M. Rosenfeld and A. Arato (eds), Habermas on Law and Democracy: Critical Exchanges (Berkeley, CA: University of California Press), 381-452.

Habermas, J. (1999a) The Inclusion of the Other: Studies in Political Theory, ed. C. Cronin and P. De Greif (Cambridge, MA: MIT Press).

Habermas, J. (1999b) Wahrheit und Rechtfertigung [Truth and justification] (Frankfurt am Main, Germany: Suhrkamp).

Habermas, J. (2001) The Postnational Constellation: Political Essays, ed. and trans. M. Pensky (Cambridge: Polity Press).

Habermas, J. (2003) The Future of Human Nature (Cambridge: Polity Press).

Hobbes, T. (1968) Leviathan (London: Penguin).

Inglehart, R. (1997) Modernization and Postmodernization: Cultural, Economic and Political Change in 43 Societies (Princeton, NJ: Princeton University Press).

Kierkegaard, S. (1980) The Sickness Unto Death: A Christian Psychological Exposition for Upbuilding and Awakening, ed. and trans. H. V. Hong and E. H. Hong (Princeton, NJ: Princeton University Press).

Lukes, S. (2003) Liberals and Cannibals: The Implications of Diversity (London: Verso).

Marshall, T. H. (1964) Class, Citizenship, and Social Development: Essays (Garden City, NY: Doubleday).

PRop (2001/02: 80) Demokrati för det nya seklet [Democracy for the new century] (Stockholm: Regeringskansliet).

Rawls, J. (1993) Political Liberalism (New York: Columbia University Press).

Sigurdson, O. (2000) Den lyckliga filosofin [The happy philosophy] (Stehag, Sweden: Brutus Östlings Bokförlag Symposion).

Skolverket (2000) En fördjupad studie av värdegrunden, Dnr 2000:1613 [An in-depth study of the value foundation] (Stockholm: Skolverket).

SOU (1990: 44) Demokrati och makt $i$ Sverige [Democracy and power in Sweden] (Stockholm: Fritzes).

SOU (2000: 1) En uthållig demokrati [A sustainable democracy] (Stockholm: Fritzes).

SOU (2001: 48) Att vara med pa riktigt [To be in it for real] (Stockholm: Fritzes).

Taylor, C. (1989) Sources of the Self: The Making of the Modern Identity (Cambridge, MA: Harvard University Press).

Wagner, P. (1994) A Sociology of Modernity: Liberty and Discipline (London: Routledge). 